\title{
Polymorphisms of the Peroxisome
} Proliferator-Activated Receptor- $\gamma$ (rs1801282) and its coactivator-1 (rs8192673) are associated with obesity indexes in subjects with type 2 diabetes mellitus

Peter Kruzliak ${ }^{1 *}$, Andreana P Haley ${ }^{2,3}$, Jovana Nikolajevic Starcevic ${ }^{4}$, Ludovit Gaspar ${ }^{5^{*}}$ and Daniel Petrovic ${ }^{4^{*}}$

\begin{abstract}
The aim of this study was to clarify whether common single nucleotide polymorphisms (SNPs) of the Peroxisome Proliferator-Activated Receptor- $\gamma$ (PPAR- $\gamma$ ) gene (rs1801282) and the Peroxisome Proliferator-Activated Receptor- $\gamma$ Coactivator-1 (PGC-1a) gene (rs8192673) are associated with obesity indexes (BMI, waist circumference) in subjects with type 2 diabetes mellitus (T2DM) in Caucasian population. The second aim was to find an association of both polymorphisms with T2DM.

Methods: Two exonic SNPs of both genes rs1801282 of the PPAR- $y$ gene and rs8192673 of the PGC-1a gene) were genotyped in 881 unrelated Slovene subjects (Caucasians) with T2DM and in 348 subjects without T2DM (control subjects).
\end{abstract}

Results: Female homozygotes with the CC genotype of the rs8192673 had higher waist circumference in comparison with subjects with other genotypes. Homozygotes (females, males) with wild allele (Pro) of the rs1801282 (Pro12Ala polymorphism) had higher waist circumference in comparison with subjects with other genotypes. In the study, there were no differences in the distributions of the rs8192673 and the rs1801282 genotypes between patients with T2DM and controls. Linear regression analyses for both polymorphisms were performed and demonstrated an independent effect of the rs1801282 of the PPAR- $y$ on waist circumference in subjects with T2DM, whereas an independent effect on waist circumference was not demonstrated for the rs8192673 of the PGC-1a gene.

Conclusions: In a large sample of the Caucasians the rs8192673 of the PGC-1a gene and the rs1801282 of the PPAR- $\gamma$ gene were associated with waist circumference in subjects with T2DM.

Keywords: Peroxisome Proliferator-Activated Receptor- $\gamma$, Peroxisome Proliferator-Activated Receptor- $\gamma$ Coactivator-1, Gene polymorphism, Association study, Type 2 diabetes mellitus, Obesity indexes

\footnotetext{
*Correspondence: peter.kruzliak@savba.sk; ludovitgaspar@gmail.com; dp.petrovic@gmail.com

'Department of Cardiovascular Diseases, International Clinical Research

Center, St Anne's University Hospital and Masaryk University, Brno, Czech Republic

${ }^{5}$ 2nd Department of Internal Medicine, University Hospital and Comenius

University, Bratislava, Slovak Republic

${ }^{4}$ Institute of Histology and Embryology, Faculty of Medicine, University of

Ljubljana, Ljubljana, Slovenia

Full list of author information is available at the end of the article
}

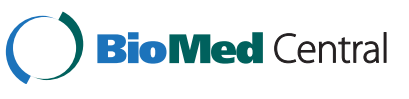

(c) 2015 Kruzliak et al.; licensee BioMed Central. This is an Open Access article distributed under the terms of the Creative Commons Attribution License (http://creativecommons.org/licenses/by/4.0), which permits unrestricted use, distribution, and reproduction in any medium, provided the original work is properly credited. The Creative Commons Public Domain Dedication waiver (http://creativecommons.org/publicdomain/zero/1.0/) applies to the data made available in this article, unless otherwise stated. 


\section{Introduction}

Diabetes mellitus (DM) is a multifactorial metabolic disorder, characterized by hyperglycemia, resulting from abnormalities in insulin secretion, insulin action, or both [1]. Diabetes prevalence has increased dramatically in many countries over the past decades. The number of people with diabetes exceeds 300 million worldwide, most of them being patients with type 2 diabetes mellitus (T2DM) and it has become one of the most common chronic diseases in the world. There are predictions, based on a large number of studies, which indicate a growing burden of diabetes, particularly in the developing countries [2-4].

There are several pathogenic mechanisms that influence the development of diabetes and its complications [5-14]. T2DM is characterised by insulin resistance, dysfunction of pancreatic beta cells and enhanced hepatic gluconeogenesis. However, the exact pathophysiology of T2DM is still unknown. Abdominal obesity, sedentary lifestyle, advancing age, genetic and epigenetic factors affecting glucose homeostasis are thought to be key contributing factors $[15,16]$.

Peroxisome proliferator-activated receptor- $\gamma$ coactivator$1(P G C-1 \alpha)$ gene is thought to be involved in three pathophysiological hallmarks of T2DM: insulin sensitivity, insulin secretion and hepatic gluconeogenesis $[17,18]$. Thus, functional sequence substitutions in PGC-1 $\alpha$ may play an important role in the development of T2DM.

Results of the association studies involving the rs 8192673 of the PGC-1 $\alpha$ gene and the rs 1801282 of the PPAR- $\gamma$ gene published so far, reported different findings, showing either an association with T2DM risk or no association [16,18-22]. Moreover, the rs8192673 of the PGC-1 $\alpha$ gene was reported to be associated with insulin resistance, obesity indices in women and with lipid metabolism and insulin secretion $[21,23,24]$.

Both the PPAR- $\gamma$ gene and the PGC-1 $\alpha$ gene are potential candidates for modifying the risk of T2DM $[6,8,25]$.

The aim of this study was to clarify whether common single nucleotide polymorphisms of the PPAR- $\gamma$ gene (rs1801282) and the PGC-1 $\alpha$ gene (rs8192673) are associated with obesity indexes (BMI, waist circumference) in subjects with T2DM in Caucasian population. The second aim was to find an association of both polymorphisms with T2DM.

\section{Materials and methods}

In this cross-sectional study, 881 consecutive patients with T2DM from the outpatients clinics for patients with diabetes from central and north-eastern regions of Slovenia were enrolled as well as 348 subjects without diabetes. The research protocol was approved by The National Medical Ethics Committee. All the subjects enrolled in the study were Slovenian and were not related. Patients were classified as having type 2 diabetes according to the current report of the American Diabetes Association [1]. After the informed consent was obtained from the patient and subjects, a detailed interview was made concerning smoking habits, the duration and treatment of diabetes, arterial hypertension, and hyperlipidemia. Patients were asked whether they were smokers at the time of recruitment ("current smoker"). The body mass index (BMI) was calculated as weight in kilograms divided by the height in square meters. Obesity was determined defined as body mass index $\geq 30 \mathrm{~kg} / \mathrm{m}^{2}$ [26].

Systolic blood pressure (SBP) and diastolic blood pressure (DBP) in the right upper arm of the patients were measured while they were sitting (2 consecutive measurements). Subjects with T2DM with systolic blood pressure $\geq 140 \mathrm{~mm} \mathrm{Hg}$ or diastolic blood pressure $\geq 85 \mathrm{~mm} \mathrm{Hg}$ and/or subjects who were using antihypertensive drugs were considered to be hypertensive [27]. Secondary causes of arterial hypertension were excluded according to normal clinical exam (no systolic murmur above renal arteries) and normal serum electrolytes (exclusion of renal failure and hyperaldosteronism) [27].

Genomic DNA was extracted from $100 \mu \mathrm{l}$ of whole blood using a Qiagen isolation kit. Genotypes of PPAR- $\gamma$ were determined as described previously [28].

Blood samples for biochemical analyses: total cholesterol, triglyceride levels, high-density lipoprotein (HDL), low density lipoprotein (LDL) level and fasting blood glucose were collected after an overnight fasting. All blood biochemical analyses were determined by standard biochemical methods in the hospital's accredited lab.

Data are expressed as means \pm standard deviations or frequencies (percentages). The chi-square test was used to compare discrete variables. Continuous clinical data were compared by an unpaired Student's $t$ test (normal distribution by Kolmogorov Smirnov test) or by MannWhitney $U$ test (for variables without normal distribution by Kolmogorov Smirnov test) or analysis of variance. A $\mathrm{p}<0.05$ was considered statistically significant. A statistical analysis was performed using the SPSS program for Windows version 20 (SPSS Inc. Illinois).

Continuous variables were expressed as means \pm standard deviations when normally distributed, and as median (interquartile range) when asymmetrically distributed. Normality was tested with the Kolmogorov-Smirnov test. Continuous clinical data were compared by an unpaired Student's $t$ test or analysis of variance (ANOVA) when normally distributed, and Mann-Whitney U-test or the Kruskal-Wallis $\mathrm{H}$-test when asymmetrically distributed. The Pearson $x^{2}$ test was used to compare discrete variables and to test whether the genotypes distributions are in HardyWeinberg equilibrium.

Pearson's correlation was performed to examine the association between independent variables. Due to the high correlation of LDL cholesterol with total cholesterol 
$(\mathrm{r}=0.86, \mathrm{p}<0.001)$ they were not included together in the same statistical model.

For determination of variables independently associated with waist circumference multivariate linear regression analyses were performed for both polymorphisms. Candidate variables to enter the models were the following: age, gender, plasma levels of LDL cholesterol and triglycerides, hypolipemic therapy, diabetes therapy, HbA1c and genotypes of the PPAR- $\gamma$ (rs1801282) and the PGC- $1 \alpha$ (rs8192673) polymorphisms. The results were presented as standardized $\beta$ coefficients and P-values for linear regression and by odds ratios and $95 \%$ CIs for logistic regression analysis.

A two-tailed $\mathrm{P}$ value less than 0.05 was considered statistically significant. A statistical analysis was performed using the SPSS program for Windows version 20 (SPSS Inc., Chicago, IL).

\section{Results}

Clinical characteristics of the cases (patients with T2DM) and controls (subjects without T2DM) are summarized in Table 1. Cases had higher frequency of arterial hypertension, obesity (defined as body mass index $\geq 30 \mathrm{~kg} / \mathrm{m}^{2}$ ) in

Table 1 Characteristics of subjects with type 2 diabetes (cases) and in subjects without diabetes (controls)

\begin{tabular}{|c|c|c|c|}
\hline Characteristics & Cases & Controls & $\mathbf{P}$ \\
\hline Number & 881 & 348 & - \\
\hline Age (years) & $63.2 \pm 10.3$ & $61.3 \pm 12.9$ & 0.1 \\
\hline Male sex (\%) & $458(52.0)$ & $173(49.7)$ & 0.3 \\
\hline Duration of diabetes (years) & $14.8 \pm 8.9$ & - & - \\
\hline Incidence of arterial hypertension (\%) & $458(52.0)$ & $103(29.6)$ & $<0.001$ \\
\hline Systolic blood pressure (mm Hg) & $148.9 \pm 28.5$ & $146.7 \pm 22.7$ & 0.06 \\
\hline Diastolic blood pressure (mm Hg) & $84.9 \pm 12.2$ & $83.5 \pm 11.8$ & 0.3 \\
\hline BMI $\left(\mathrm{kg} / \mathrm{m}^{2}\right)^{1}$ & $30.4 \pm 4.2$ & $28.5 \pm 3.5$ & $<0.001$ \\
\hline Obesity $^{2}$ & $436(49.5)$ & $87(25.0)$ & $<0.001$ \\
\hline Smokers (\%) & $61(6.9)$ & $45(12.9)$ & $<0.001$ \\
\hline Glucose (mmol/l) & $8.32 \pm 2.52$ & $5.18 \pm 0.87$ & $<0.001$ \\
\hline $\mathrm{Hba} 1 c^{3}$ & $8.07 \pm 1.54$ & - & - \\
\hline $\operatorname{hsCRP}(\mathrm{mg} / \mathrm{l})^{4 *}$ & $2.1(1.0-4.1)$ & $1.1(0.6-2.7)$ & $<0.001$ \\
\hline Fibrinogen $(g / l)$ & $4.10 \pm 1.15$ & $3.76 \pm 0.83$ & $<0.001$ \\
\hline Hypolipemic drugs & $698(79.2)$ & $66(19.0)$ & $<0.001$ \\
\hline Total cholesterol (mmol/l) & $5.5 \pm 1.4$ & $5.9 \pm 1.6$ & $<0.001$ \\
\hline HDL cholesterol (mmol/l) & $1.1 \pm 0.3$ & $1.3 \pm 0.4$ & $<0.001$ \\
\hline LDL cholesterol (mmol/l) & $2.6 \pm 0.9$ & $3.0 \pm 1.1$ & $<0.001$ \\
\hline Triglycerides (mmol/l)* & $1.9(1.2-2.7)$ & $1.3(0.9-1.9)$ & $<0.001$ \\
\hline \multicolumn{4}{|c|}{$\begin{array}{l}\text { Continuous variables were expressed as means } \pm \text { standard deviations when } \\
\text { normally distributed and as median (interquartile range) when asymmetrically } \\
\text { distributed. } \\
{ }^{1} \mathrm{BMl} \text { - body mass index, }{ }^{2} \text { obesity is defined as } \mathrm{BMI} \geq 30 \mathrm{~kg} / \mathrm{m}^{2},{ }^{3} \mathrm{Hba} 1 \mathrm{c}-\text { glycated } \\
\text { hemoglobin } \mathrm{A} 1 \mathrm{c},{ }^{4} \mathrm{hsCRP} \text { - high sensitive } \mathrm{C} \text { reactive protein, }{ }^{*} \text { Continuous variables } \\
\text { with asymmetric distribution. }\end{array}$} \\
\hline
\end{tabular}

comparison with controls (Table 1). The values of body mass index (BMI), glucose, high sensitive $\mathrm{C}$ reactive protein (hsCRP), lipid parameters, fibrinogen levels were higher in subjects with T2DM. Additionally they had a higher frequency of hypolipemic therapy with higher values of triglycerides. On the contrary, total cholesterol, LDL cholesterol, and HDL cholesterol levels were higher in control subjects, as well as the percentage of current smokers. Results show no statistical significant differences in age and blood pressure values between cases and controls (Table 1).

The genotypes of both polymorphisms were in HardyWeinberg equilibrium (rs1801282 cases: $x^{2}=3.22, p=0.07$; controls: $x^{2}=0.56, p=0.45$; rs1801282 cases: $x^{2}=0.07$, $\mathrm{p}=0.79$; controls: $\mathrm{x}^{2}=2.5, \mathrm{p}=0.11$ ).

The distribution of PPAR- $\gamma$ gene (rs1801282) and the $P G C-1 \alpha$ gene (rs8192673) among patients with T2DM and control subjects without T2DM is shown in Table 2 . There were no differences in the distributions of the rs8192673 and the rs1801282 genotypes between patients with T2DM and control subjects without T2DM (Table 2).

The rs8192673 polymorphism was associated with waist circumference in subjects with T2DM. Specifically, female homozygotes with mutated allele (CC genotype) had higher waist circumference in comparison with subjects with other genotypes (Figure 1). Moreover, the rs1801282 (Pro12Ala polymorphism) polymorphism was associated with waist circumference in subjects with T2DM. Namely, subjects with the CC genotype (men and women, men, women) had

Table 2 Genotype distribution and allele frequencies of the rs8192673 of the PGC-1a gene and rs1801282 of the PPAR- $\gamma$ gene in subjects with T2DM and in control subjects

\begin{tabular}{llll}
\hline Polymorphism & T2DM $\mathbf{n = 8 8 1}$ & Controls $\mathbf{n}=\mathbf{3 4 8}$ & $\mathbf{p}$ \\
\hline rs8192673 & & & \\
$\Pi T$ & $467(53.0)$ & $161(46.3)$ & \\
TC & $334(37.9)$ & $147(42.2)$ & 0.08 \\
CC & $80(9.1)$ & $40(11.5)$ & \\
Allele frequencies & & & 0.02 \\
T & $1268(71.9)$ & $469(67.4)$ & \\
C & $494(28.1)$ & $227(32.6)$ & \\
rs1801282 & & & \\
CC & $631(71.6)$ & $250(71.8)$ & \\
CG & $228(25.9)$ & $85(24.5)$ & \\
GG & $22(2.5)$ & $13(3.7)$ & \\
Allele frequencies & & & \\
C & $1490(84.6)$ & $585(84.1)$ & \\
G & $272(15.4)$ & $111(15.9)$ & \\
\hline
\end{tabular}

Results were presented as frequency (percentage). 


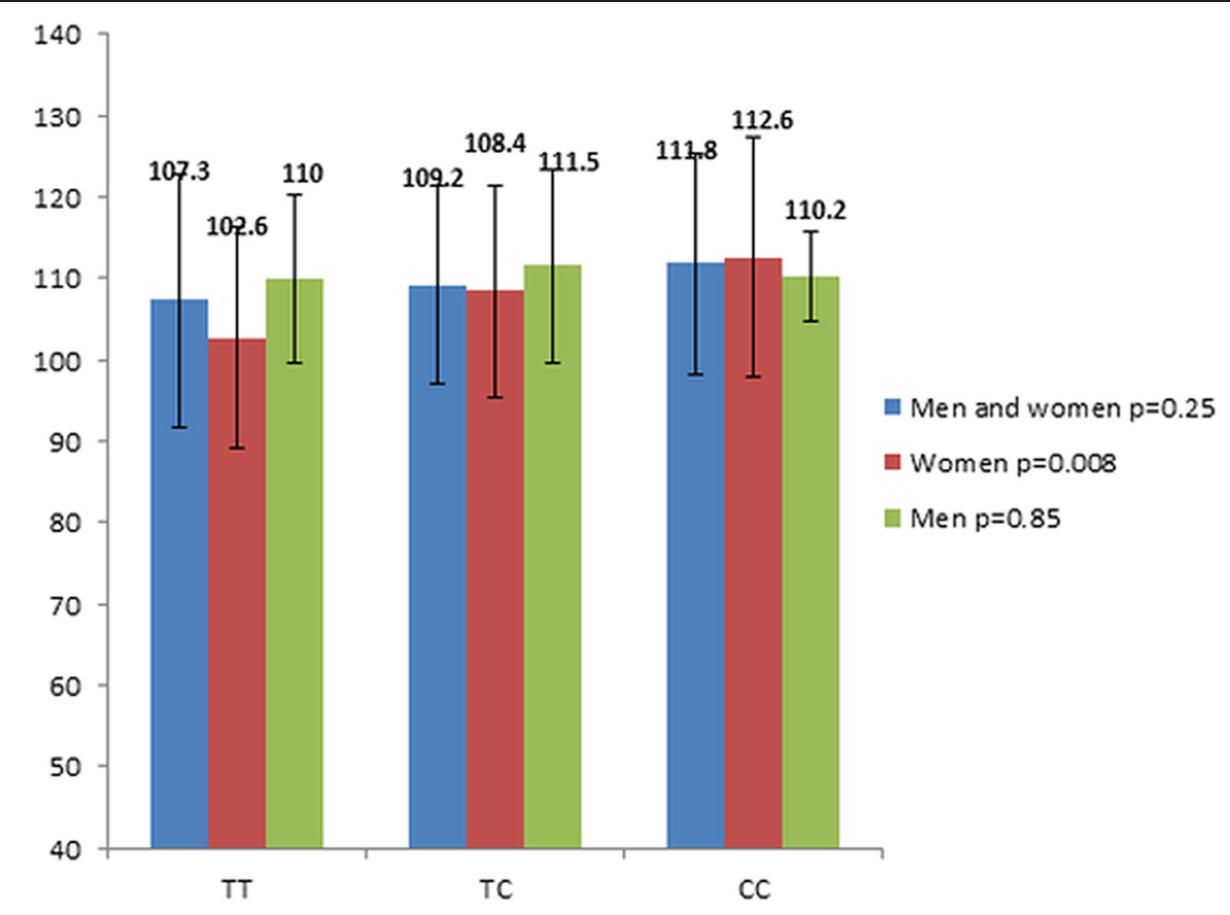

Figure 1 Waist circumference $(\mathrm{cm})$ with regard to rs8192673 genotypes of the PGC-1a gene.

higher waist circumference in comparison with subjects with other genotypes (Figure 2).

Linear regression analyses for both polymorphisms were performed and demonstrated an independent effect of the rs1801282 of the PPAR- $\gamma$ on waist circumference in subjects with T2DM, whereas an independent effect on waist circumference was not demonstrated for the rs8192673 of the $P G C-1 \alpha$ gene (Table 3).

\section{Discussion}

In this cross-sectional association study that involved more than one thousand Caucasians, the rs8192673 of the PGC-1 $\alpha$ gene and the rs 1801282 of the PPAR- $\gamma$ gene failed to be associated with T2DM. These findings differ from an early report in the Slovene population from 2004 [28] and from the report from another Caucasian population [18], in which the authors reported a link

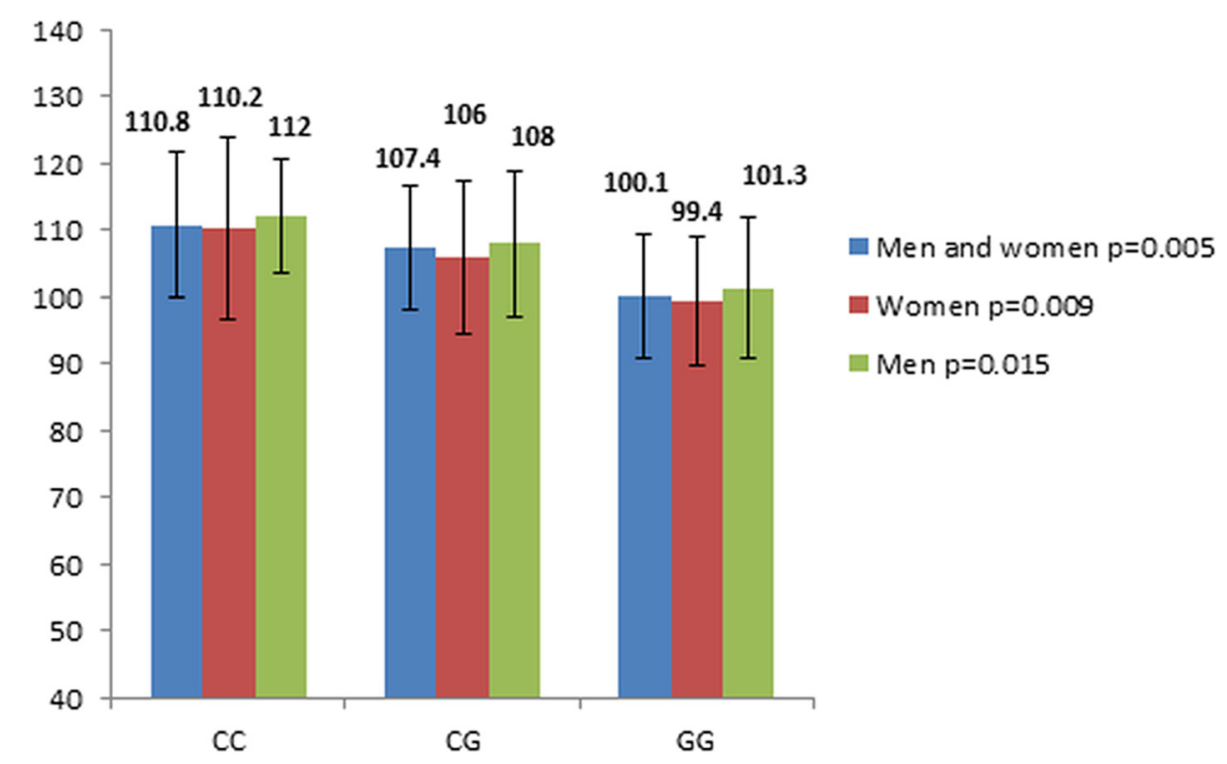

Figure 2 Waist circumference $(\mathrm{cm})$ with regard to rs1801282 genotypes of the PPAR- $\gamma$ gene. 


\begin{tabular}{|c|c|c|}
\hline \multicolumn{3}{|l|}{ rs8192673 of the PGC-1a gene } \\
\hline & $\beta$ & $\mathbf{p}$ \\
\hline Age (year) & -0.09 & $<0.001$ \\
\hline Gender ( $0=$ male, $1=$ female) & -1.179 & 0.019 \\
\hline Triglycerides (mmol/L) & 0.684 & $<0.001$ \\
\hline LDL cholesterol (mmol/L) & 0.288 & 0.759 \\
\hline HbA1c (\%) & 0.013 & 0.957 \\
\hline Insulin therapy (0 = no, 1 = yes) & -0.864 & 0.101 \\
\hline Hypolipemic therapy ( $0=$ no, $1=$ yes $)$ & -0.479 & 0.786 \\
\hline $\mathrm{TC}^{*}$ & 0.537 & 0.271 \\
\hline$C C^{*}$ & 0.646 & 0.54 \\
\hline \multicolumn{3}{|l|}{ rs 1801282 of the PPAR- $\gamma$} \\
\hline Age (year) & -0.007 & 0.807 \\
\hline Gender ( 0 = male, 1 = female) & -1.213 & 0.016 \\
\hline Triglycerides (mmol/L) & -0.698 & $<0.001$ \\
\hline LDL cholesterol (mmol/L) & -0.269 & 0.759 \\
\hline $\mathrm{HbA1c}(\%)$ & 0.134 & 0.954 \\
\hline Insulin therapy (0 = no, 1 = yes) & -0.812 & 0.122 \\
\hline Hypolipemic therapy ( $0=$ no, $1=$ yes) & 0.550 & 0.755 \\
\hline$C G^{* *}$ & -0.673 & 0.024 \\
\hline $\mathrm{GG}^{* *}$ & -0.832 & 0.035 \\
\hline
\end{tabular}

*Reference genotype was $\Pi$; **Reference genotype was CC.

between the rs 8192673 of the PGC-1 $\alpha$ gene and T2DM. The present finding in the Slovene population is in accordance with few other reports in the Caucasians $[16,20]$, the Japanese population [21] and the Pima Indians [22], which also failed to demonstrate an association with T2DM. Moreover, rs1801282 (Pro12Ala polymorphism) of the PPAR- $\gamma$ was also implicated in several studies to affect the T2DM risk [29]. Mekhani and coworkers reported that in the Iranian population there was a lower frequency of Ala allele in subjects with T2DM when these were compared to control subjects without T2DM (5.9\% vs. 9.4\%, $\mathrm{p}=0.005)$. Besides being associated with a decreased risk of T2DM, this polymorphism was also associated with greater insulin sensitivity [28]. In the present study carried out in the Slovene population with T2DM there was no statistically significant difference in allele distribution, the frequency of the Ala allele was $15.4 \%$ and $15.9 \%$ in subjects with T2DM and in controls, respectively.

Due to some reports of an association of both polymorphisms (rs8192673, rs1801282) with obesity indexes $[18,24,29]$, the influence of both polymorphisms on obesity indexes (BMI, waist circumference) in subjects with T2DM was also examined. In the present study in
Slovene subjects with T2DM, the homozygous females with wild alleles had lower waist circumference in comparison with homozygous females with mutated alleles, whereas the effect of the rs 8192673 genotypes was not demonstrated in males with T2DM. This finding is in accordance with an early report by Esterbauer and coworkers on general population [24]. They reported that wild allele was associated with lower waist circumference in middle-aged women, whereas there was no association between rs8192673 alleles in middle-aged men. Contrary to these reports, Ek and co-workers failed to report an association with another obesity index, namely BMI in their male/female type 2 diabetes and control populations $[18,24]$. In the present study, the rs 1801282 (Pro12Ala polymorphism) polymorphism was also associated with waist circumference in subjects with T2DM. Namely, homozygotes (females, males) with wild allele (Pro) had higher waist circumference in comparison with subjects with other genotypes. Moreover, linear regression analyses for both polymorphisms were performed and demonstrated an independent effect of the rs1801282 of the PPAR- $\gamma$ on waist circumference in subjects with T2DM, whereas an independent effect on waist circumference was not demonstrated for the rs8192673 of the $P G C-1 \alpha$ gene. Contrary to our study, the Pro12Ala polymorphism did not show a significant effect on anthropometric and biochemical parameters in Iranian subjects with T2DM [29].

The exact mechanism of both polymorphisms is not completely clear, but they are expected to have various effects including affecting the insulin sensitivity of peripheral organs $[11,23]$. However, despite being associated with some obesity markers in this study and in several other studies, the influence of both polymorphisms is not strong enough to be associated with increased risk of T2DM [18,24,29]. Interactions among genetic (gene variants) and/or clinical factors (physical inactivity, diet, obesity...), which may have stronger effects in combination, are expected to increase the power of risk prediction of multifactorial disorders (including T2DM) and advance our understanding of the underlying biology of multifactorial disorders $[2,3,30,31]$.

Beside these two polymorphisms of the $P G C-1 \alpha$ and the PPAR- $\gamma$ genes (rs8192673 and rs1801282) several other genes have been so far implicated by linkage analysis, association studies, and genome-wide association studies in the development of obesity and obesity-associated phenotypes [32-38]. Proteasome modulator 9 (PSMD9) gene was reported to be responsible for the linkage to obesity and obesity-associated phenotypes (waist circumference, overweight status) at the locus 12q24 [33]. Frayling and coworkers showed for the first time the contribution of the SNP rs9939609 in fat mass and obesity-associated gene FTO on excess of weight [37]. Common genetic variants of 
FTO-rs9939609 have positive associations with BMI and rs17782313 of the melanocortin 4 receptor (MC4R) gene with neck circumference in women [32]. Mutation in MC4R gene was found to be associated with morbid obesity in human beings [38]. Recently the association between the Fas apoptotic inhibitory molecule 2 (FAIM2)-rs7138803 polymorphism and greater obesity risk has been replicated [35]. Moreover, rs6232 of the proprotein convertase subtilisin/kexin-type 1 (PCSK1) was associated BMI [34]. Several different mechanisms of action have been proposed [32-36]. PCSK1 was found to activate precursors proopiomelanocortin (POMC), proinsulin and prorenin (citat). Similarly, since PSMD9 is a coactivator of insulin gene transcription, and in pancreatic overexpression of transgenic mice cause diabetes, PSMD9 variants may contribute to T2DM as well as to obesity $[33,39,40]$. Moreover, miRNAdependent regulation of fat distribution by miR-196a 2 and miR-1908-dependent regulation of lipid metabolism has recently been reported [36]. Additionally, according to the study of Corella and co-workers epigenetic factors may also be involved in the development of obesity [35].

Our study has few limitations, one of them being the cross-sectional design of the study. One of the major limitations of the current study is the absence of a replication study with independent samples. Another weakness is a relatively limited sample size. However, all the participants were enrolled from an ethnically homogenous population. Thus further studies are needed to replicate our findings in different ethnic groups with a larger sample size.

In conclusion, in a large sample of the Caucasians the rs8192673 of the PGC-1 $\alpha$ gene and the rs 1801282 of the PPAR- $\gamma$ gene were associated with waist circumference in subjects with T2DM.

\section{Competing interests}

The authors declare that they have no competing interests.

\begin{abstract}
Authors' contributions
PK participated in study design, carried out the molecular genetic studies, and drafted the manuscript. APH helped to draft the manuscript, and revised the article for important intellectual content. JNS participated in manuscript writing and performed statistical analysis. LG revised the article for important intellectual content. DP conceived of the study, and participated in its design and coordination and helped to draft the manuscript. All authors read and approved the final manuscript.
\end{abstract}

\section{Acknowledgement}

This study was supported by the grant of the European Regional Development Fund_-Project FNUSA-ICRC No. CZ.1.05/1.1.00/02.0123).

\footnotetext{
Author details

'Department of Cardiovascular Diseases, International Clinical Research Center, St Anne's University Hospital and Masaryk University, Brno, Czech Republic. ${ }^{2}$ Department of Psychology, The University of Texas, Austin, TX, USA. ${ }^{3}$ University of Texas Imaging Research Center, Austin, TX, USA. ${ }^{4}$ Institute of Histology and Embryology, Faculty of Medicine, University of Ljubljana, Ljubljana, Slovenia. ${ }^{5}$ 2nd Department of Internal Medicine, University Hospital and Comenius University, Bratislava, Slovak Republic.
}

Received: 8 January 2015 Accepted: 20 March 2015

Published online: 28 April 2015

\section{References}

1. American Diabetes Association. Diagnosis and Classification of Diabetes Mellitus. Diabetes Care. 2012;35 Suppl 1:S64-71.

2. Du Y, Heidemann C, Gößwald A, Schmich P, Scheidt-Nave C. Prevalence and comorbidity of diabetes mellitus among non-institutionalized older adults in Germany - results of the national telephone health interview survey 'German Health Update (GEDA)' 2009. BMC Public Health. 2013;13:166.

3. Shaw JE, Sicree RA, Zimmet PZ. Global estimates of the prevalence of diabetes for 2010 and 2030. Diabetes Res Clin Pract. 2010;87:4-14.

4. Whiting DR, Guariguata L, Weil C, Shaw J. IDF diabetes atlas: global estimates of the prevalence of diabetes for 2011 and 2030. Diabetes Res Clin Pract. 2011;94:311-21.

5. Shigemizu D, Abe T, Morizono T, Johnson TA, Boroevich KA, Hirakawa Y, et al. The Construction of Risk Prediction Models Using GWAS Data and Its Application to a Type 2 Diabetes Prospective Cohort. PLoS One. 2014;9(3):e92549.

6. Xi B, Takeuchi F, Meirhaeghe A, Kato N, Chambers JC, Morris AP, et al. Associations of genetic variants in/near body mass index-associated genes with type 2 diabetes: a systematic meta-analysis. Clin Endocrinol (Oxf). 2014 Feb 16. doi:10.1111/cen.12428.

7. Klemenc-Ketis Z, Peterlin B. Family history as a predictor for disease risk in healthy individuals: a cross-sectional study in Slovenia. PLoS One. 2013;8(11), e80333.

8. Deeb SS, Brunzell JD. The role of the PGC1a Gly482Ser polymorphism in weight gain due to intensive diabetes therapy. PPAR Res. 2009;2009:649286.

9. Petrovic MG, Kunej T, Peterlin B, Dovc P, Petrovic D. Gly482Ser polymorphism of the peroxisome proliferator-activated receptor-gamma coactivator-1 gene might be a risk factor for diabetic retinopathy in Slovene population (Caucasians) with type 2 diabetes and the Pro12Ala polymorphism of the PPARgamma gene is not. Diabetes Metab Res Rev. 2005;21(5):470-4.

10. Maver A, Hristovski D, Rindflesch TC, Peterlin B. Integration of data from omic studies with the literature-based discovery towards identification of novel treatments for neovascularization in diabetic retinopathy. Biomed Res Int. 2013;2013:848952.

11. Soyal S, Krempler F, Oberkofler H, Patsch W. PGC-1alpha: a potent transcriptional cofactor involved in the pathogenesis of type 2 diabetes. Diabetologia. 2006;49(7):1477-88.

12. Habek JC, Lakusic N, Kruzliak P, Sikic J, Mahovic D, Vrbanic L. Left ventricular diastolic function in diabetes mellitus type 2 patients: correlation with heart rate and its variability. Acta Diabetol. 2014;51:999-1005.

13. Sharma S, Saxena S, Srivastav K, Shukla R, Mishra N, Meyer CH, et al. Nitric oxide and oxidative stress is associated with severity of diabetic retinopathy and retinal structural alterations. Clin Experiment Ophthalmol. 2015. doi:10.1111/ceo.12506.

14. Bendzala M, Kruzliak P, Gaspar L, Soucek M, Mrdovic I, Sabaka P, et al. Prognostic significance of dipping in older hypertensive patients. Blood Press. 2015;24:103-10.

15. O'Rahilly S, Barroso I, Wareham NJ. Genetic factors in type 2 diabetes: the end of the beginning? Science. 2005;307:370-3.

16. Barroso I, Luan J, Middelberg RP, Harding AH, Franks PW, Jakes RW, et al. Candidate gene association study in type 2 diabetes indicates a role for genes involved in $\beta$-cell function as well as insulin action. PLoS Biol. 2003;1:41-55.

17. Pratley RE, Thompson DB, Prochazka M, Baier L, Mott D, Ravussin E, et al. An autosomal genomic scan for loci linked to prediabetic phenotypes in Pima Indians. J Clin Invest. 1998;101:1757-64.

18. Ek J, Andersen G, Urhammer SA, Gaede PH, Drivsholm T, Borch-Johnsen K, et al. Mutation analysis of peroxisome proliferator-activated receptor-gamma coactivator-1 (PGC-1) and relationships of identified amino acid polymorphisms to Type II diabetes mellitus. Diabetologia. 2001;44(12):2220-6.

19. Andersen G, Hansen T, Gharani N, Frayling TM, Owen KR, Sampson M, et al. A common Gly482Sser polymorphism of PGC-1 is associated with type 2 diabetes mellitus in two European populatins (Abstract). Diabetes. 2002;51 suppl 2:A49.

20. Lacquemant C, Chikri M, Boutin P, Samson C, Froguel P. No association between the G482S polymorphism of the proliferator-activated receptor- $\gamma$ coactivator-1 gene and Type II diabetes in French Caucasias. Diabetologia. 2002:45:602-3.

21. Hara K, Tobe $K$, Okada T, Kadowaki H, Akanuma Y, Ito C, et al. A genetic variation in the PGC-1 gene could confer insulin resistance and susceptibility to Type II diabetes. Diabetologia. 2002;45:740-3. 
22. Muller YL, Bogardus C, Beamer BA, Shuldiner AR, Baier LJ. A functional variant in the peroxisome proliferator-activated receptor gamma2 promoter is associated with predictors of obesity and type 2 diabetes in Pima Indians. Diabetes. 2003;52(7):1864-71.

23. Muller YL, Bogardus C, Pedersen O, Baier L. A Gly482Ser missense mutation in the peroxisome proliferator-activated receptor- $\gamma$ coactivator- 1 is associated with altered lipid oxidation and early insulin secretion in Pima Indians. Diabetes. 2003;52:895-8.

24. Esterbauer $H$, Oberkofler $H$, Linnemayr $V$, Iglseder $B$, Hedegger $M$, Wolfsgruber $P$, et al. Peroxisome proliferator-activated receptor-gamma coactivator-1 gene locus: associations with obesity indices in middle-aged women. Diabetes. 2002:51(4):1281-6.

25. Parikh H, Groop L. Candidate genes for type 2 diabetes. Rev Endocr Metab Disord. 2004;5:151-76.

26. Janssen I, Katzmarzyk PT, Ross R. Waist circumference and not body mass index explains obesity-related health risk. Am J Clin Nutr. 2004;79(3):379-84.

27. Mancia G, De Backer G, Dominiczak A, Cifkova R, Fagard R, Germano G. et al; European Society of Hypertension; European Society of Cardiology. 2007 ESH-ESC Guidelines for the management of arterial hypertension: the task force for the management of arterial hypertension of the European Society of Hypertension (ESH) and of the European Society of Cardiology (ESC). Blood Press. 2007;16:135-232.

28. Kunej T, Globocnik Petrovic M, Dovc P, Peterlin B, Petrovic D. A Gly482Ser polymorphism of the peroxisome proliferator-activated receptor-gamma coactivator-1 (PGC-1) gene is associated with type 2 diabetes in Caucasians. Folia Biol (Praha). 2004;50(5):157-8.

29. Meshkani R, Taghikhani M, Larijani B, Bahrami Y, Khatami S, Khoshbin E, et al. Pro12Ala polymorphism of the peroxisome proliferator-activated receptor-gamma2 (PPARgamma-2) gene is associated with greater insulin sensitivity and decreased risk of type 2 diabetes in an Iranian population. Clin Chem Lab Med. 2007;45(4):477-82.

30. Cordell HJ. Detecting gene-gene interactions that underlie human diseases. Nat Rev Genet. 2009;10:392-404.

31. Pan W, Basu S, Shen X. Adaptive tests for detecting gene-gene and gene- environment interactions. Hum Hered. 2011;72:98-109.

32. Marcadenti A, Fuchs FD, Matte U, Sperb F, Moreira LB, Fuchs SC. Effects of FTO RS9939906 and MC4R RS17782313 on obesity, type 2 diabetes mellitus and blood pressure in patients with hypertension. Cardiovasc Diabetol. 2013;12:103.

33. Gragnoli C. Overweight condition and waist circumference and a candidate gene within the 12q24 locus. Cardiovasc Diabetol. 2013;12:2.

34. Gu Q, Yazdanpanah M, van Hoek M, Hofman A, Gao X, de Rooij FW, et al. Common variants in PCSK1 influence blood pressure and body mass index. J Hum Hypertens. 2015;29(2):82-6.

35. Corella D, Sorlí JV, González Jl, Ortega C, Fitó M, Bulló M, et al. Novel association of the obesity risk-allele near Fas Apoptotic Inhibitory Molecule 2 (FAIM2) gene with heart rate and study of its effects on myocardial infarction in diabetic participants of the PREDIMED trial. Cardiovasc Diabetol. 2014;13:5.

36. Ghanbari M, Sedaghat S, de Looper HW, Hofman A, Erkeland SJ, Franco OH, et al. The association of common polymorphisms in miR-196a2 with waist to hip ratio and miR-1908 with serum lipid and glucose. Obesity (Silver Spring). 2015;23(2):495-503.

37. Frayling TM, Timpson NJ, Weedon MN, Zeggini E, Freathy RM, Lindgren CM, et al. A common variant in the FTO gene is associated with body mass index and predisposes to childhood and adult obesity. Science. 2007;316:889-93.

38. Vaisse C, Clement K, Guy-Grand B, Froguel P. A frameshift mutation in MC4R is associated with a dominant form of obesity. Nature Genet. 1998;20:113-4.

39. Thomas MKYK, Tenser MS, Wong GG, Habener JF. Bridge-1, a novel PDZ- domain coactivator of E2A-mediated regulation of insulin gene transcription. Mol Cell Biol. 1999;19:8492

40. Volinic JL, Lee JH, Eto K, Kaur V, Thomas MK. Overexpression of the coactivator bridge-1 results in insulin deficiency and diabetes. Mol Endocrinol. 2006;20:167.

\section{Submit your next manuscript to BioMed Central and take full advantage of:}

- Convenient online submission

- Thorough peer review

- No space constraints or color figure charges

- Immediate publication on acceptance

- Inclusion in PubMed, CAS, Scopus and Google Scholar

- Research which is freely available for redistribution

Submit your manuscript at www.biomedcentral.com/submit 